\title{
Progressive multifocal leucoencephalopathy limited to the posterior fossa as first manifestation of HIV infection
}

Leucoenfalopatia multifocal progressiva limitada à fossa posterior como manifestação inicial de infecção por HIV Ana P. Sousa', Paulo Santos' ${ }^{1}$ Claudia Fernandes², Rui Pedrosa ${ }^{3}$

A healthy 58-year-old male presented with dysarthria, bilateral horizontal nystagmus, right dysmetria, and marked gait ataxia, which had started 6 days before, after falling from a tree. MRI (Figure) revealed lesions in the right cerebellum extending to the peduncle and pons. Thorough laboratory investigations revealed a positive HIV-1 serology with a serum
CD4 count of 47 and a positive PCR for JC virus in otherwise normal CSF, establishing the diagnosis of progressive multifocal leukoencephalopathy (PML).

PML presentation with lesions confined to the posterior fossa alone is unusual ${ }^{1,2}$ and descriptions as the first manifestation of HIV are very rare ${ }^{3}$.
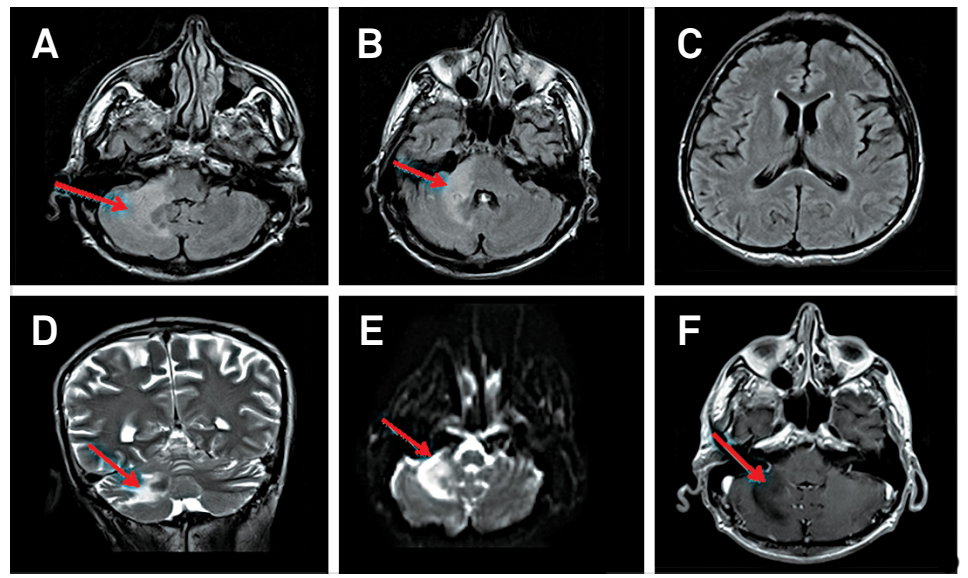

A, B and C: Axial Flair; D: Coronal T2; E: Axial DWI; F: Axial Gd-T1.

Figure. An MRI (1,5 Tesla) of the brain showing a lesion (arrow) in the right cerebellar white matter extending to right cerebellar peduncle and pons. This lesion is hyperintense on T2/Flair weighted image (A, B and D) and hypointense on T1, without mass effect or gadolinium enhancement (F) and with diffusion restriction (E). The rest of the brain parenchyma is within normal limits (C).

\footnotetext{
1. Berger JR, Aksamit AJ, Clifford DB, Davis L, Koralnik IJ, James J. Sejvar $J J$ et al. PML diagnostic criteria: consensus statement from the AAN Neuroinfectious Disease Section. Neurology. 2013;80(15):1430-8. http://dx.doi.org/10.1212/WNL.0b013e31828c2fa1

2. Lima MA. Progressive multifocal leukoencephalopathy: new concepts. Arq Neuropsiquiatr. 2013;71(9B):699-702. http://dx.doi.org/10.1590/0004-282X20130154
}

3. Lima MA, Andrade FV, Etchebehere RM, Silva-Vergara ML. [Progressive multifocal leukoencephalopathy as initial manifestation of acquired immunodeficiency]. Rev Soc Bras Med Trop. 1998;31(6):569-74. Portuguese. http://dx.doi.org/10.1590/S0037-8682199800060001

\footnotetext{
${ }^{1}$ Centro Hospitalar do Oeste, Departamento de Neurologia, Caldas da Rainha, Portugal;

${ }^{2}$ Centro Hospitalar do Oeste, Departamento de Doenças Infecciosas, Caldas da Rainha, Portugal;

${ }^{3}$ Centro Hospitalar de Lisboa Central EPE, Departamento de Neurologia, Lisboa, Portugal.

Correspondence: Ana P. Sousa; Centro Hospitalar do Oeste, Departamento de Neurologia; Rua Diário de Notícias, 2500-176; Caldas da Rainha, Portugal;

E-mail:apdiogosousa@gmail.com

Conflict of interest: There is no conflict of interest to declare.

Received 09 December 2014; Received in final form 28 December 2014; Accepted 21 January 2015.
} 